Unity Journal

Vol. III, 266-277, 2022

Doi:https://doi.org/10.3126/unityj.v3i01.43331

Prithvi Narayan Shah Research Center

Directorate General of Military Training, Nepali Army

Kathmandu, Nepal

\title{
Evolving Dimension of Security: Bioterrorism
}

\section{Pankaj Kumar Yadav}

\section{Abstract}

Bioterrorism became a burning issue in the USA after the human-induced incidence of Anthrax and the attack on WTO in 2001. At present, the world is trapped in the COVID 19 pandemic having an estimated monetary loss of 76.69 billion USD, engulfed more than 4.5 million people, and 211 million suffering to date. There is increasing concern toward bioterrorism globally which can happen either intentionally or due to poor laboratory practices. In recent decades technological progress in bioscience has simplified the development of bioweapons. Moreover, the advancement of genetic engineering is chronic biologically. Over a hundred pathogens have been identified as possible bioterrorism agents. The research article aims to explore bioterrorism as an evolving dimension of threat to the public and national security in developing countries like Nepal. In present article introduction section deals with background, statement of the problem and rationale of our study. The main body deals with biological agents of bioterriorism and their targets, history, present scenario of bioterrorism. Finally, awareness and control measures, challenge and prospects of biosecurity in Nepal. The ubiquity of biological equipment, technical knowledge and ease of production has stimulated the threat of bioterrorism. Some of the challenging dimensions are agroterrorism and bioterrorism because the attack is very difficult to detect and has a devastating effect in a short period. The social and environmental consequences of these attacks can be catastrophic. The study revealed that it would be better to pay attention and go for precaution before the occurrence of bioterror. Improving forensic techniques of the national security wing for detecting and disabling biological weapons will assist in rapid detection. The restriction against easy access to potential bioagents, physical protection, border controls, risk policies and strict law enforcement are the major steps for ensuring biosecurity.

Keywords: Biosecurity, Covid-19, Pandemic, Quarantine

\section{Introduction}

Security is a multi dimensional concept that evolves along with the several threats that emerge in the world. The word security is derived from the Latin word 'securitas' meaning free from fear and anxiety (Etymonline, 2020). Security, according to Haq (1995), is a desire that all people have in their homes, communities, workplaces, and surroundings. It encompasses the perseverance to potential damage or injury and the sense of being protected. In past when the concept of national security 
emerged, it only meant protection of national independence, sovereignty and territory. The Security Council of the United Nations (UN) widened the scope of national security by incorporating the notion of human security. International events like World War II (19391945), the Cold War (1947- 1991), the formation of the Non-Aligned Movement (1955), and globalization are the factors that helped in redefining national security (Giri, 2021; Maier, 1990). However, as the definition of security has broadened, it has evolved to include political, economic, environmental, and identity factors (Karki, 2021). The emerging dimensions of security consist not only against war and different aspects of unorganized brutality, but also against hunger, diseases, race and caste-based discrimination, nuclear arsenals, terrorist act, cybercrime, economic disparity, migration, environmental degradation, climate change, and many more. All the nations around the globe are facing various types of security threats. Nepal is a Himalayan landlocked country known as a "yam between two stones" because it is situated between the two largest countries of Asia, India and China. This poses several internal and external security dangers to Nepal, such as bioterrorism and trans-border crime (Chaturvedy \& Malone, 2012; Giri, 2021). Weapons had evolved from spears to devious biological weapons over time.

In the preceding paragraph, dimensions of security were discussed. In the following paragraph, we will elucidate biological terrorism. Bioterrorism is defined as the intentional use of pathogenic biological agents like viruses, bacteria, fungi, or toxins from living organisms to cause death or disease in humans, animals, or plants (Ackerman \& Moran, 2004; Rasco \& Bledsoe, 2004; Balali-Mood et al., 2014).
Biological warfare is generally aimed toward invader military forces to incapacitate or kill soldiers, while bioterrorism is to terrify and brutalize civilian populations (Agrios, 2017). The use of biological weapons by groups or individuals is influenced by personal, religious, ecological, social, or political beliefs (Sinha \& Singh, 2016). Bioterrorism agents are simple to manufacture, costeffective to deploy, and target-specific can cause widespread casualties with minimal logistical requirements (Sinha \& Singh, 2016; Croddy et al., 2002). Terrorism is high on NATO's (North Atlantic Treaty Organization) priority list, as they take effective action on chemical, biological, radiological, and nuclear dangers (Sinha \& Singh, 2016). Over the last 25 years, global terrorist attacks have transitioned toward the use of more lethal weapons to cause widespread devastation and massive civil causalities using chemical, biological, radiological, or nuclear materials (Sinha \& Singh, 2016). Biological weapons have long been referred to as the "poor man's atomic bomb as cost for destructive impact is only one dollar per square kilometre (Acheson, 2021; Douglass \& Livingstone, 1987).

Biological weapons are incredibly cheap when compared to the cost of a nuclear weapons program. One gram of toxin is thought to be enough to kill ten million people. Scud missile containing botulinum toxin could affect an area of 3700 sq. $\mathrm{km}$, which is 16 times larger than the area affected by sarin a nerve chemical (Acheson, 2021; Debnath et al., 2010). Biological agents have the potential to grow and multiply rapidly. Anthrax can survive in the soil for at least 40 years so it is extremely difficult to eradicate (Acheson, 2021; Christopher et al., 1997a). Many countries, including China, France, India, Iran, Iraq, North Korea, Russia, and 
many others, are pursuing biological weapons (Sinha \& Singh, 2016). Leading countries like the USA, Russia, China and even India, are working on biosecurity. There is growing concern among scientists that the leading nation can use bioweapon for increasing their monopoly in the market to achieve national economic progress.

\section{Study Methods}

A qualitative analysis was done from selected literature available from published articles, journals, books, news and comparative studies from different secondary sources. Then the sufficient discussion was made from the extracted data and from which conclusion was drawn.

\section{Biological agents of bioterrorism}

The various microorganism can be utilized as agents of bioterrorism possessing characteristics like easy availability, contagiousness, suitability for infective dissemination, ineffective treatment and mortality. According to the World Organization for Animal Health, eighty percent of bioterrorism pathogens are of animal origin, and sixty percent of human pathogens are zoonotic (OIE, 2021). Numerous animal pathogens like Foot and mouth disease virus, Bacillus anthracis, and African swine fever virus are easily and

\section{Table 1: Classification of biological weapons}

\begin{tabular}{|c|c|c|c|}
\hline Category & Disease Infection & Pathogen (Agents) & Spread criteria \\
\hline A & $\begin{array}{l}\text { Anthrax } \\
\text { Botulism } \\
\text { Plague } \\
\text { Smallpox } \\
\text { Tularemia Viral hemorrhagic } \\
\text { fevers, } \\
\text { Ebola, Marburg } \\
\text { Lassa, Machupo }\end{array}$ & $\begin{array}{l}\text { Bacillus anthracis } \\
\text { Clostridium botulinum toxin } \\
\text { Yersinia pestis } \\
\text { Variola major (Orthopox virus) } \\
\text { Francisella tularensis } \\
\text { Filo viruses } \\
\text { Arena viruses }\end{array}$ & $\begin{array}{l}\text { High Mortality, } \\
\text { dis s e m in a te } \\
\text { easily, needs } \\
\text { special action }\end{array}$ \\
\hline
\end{tabular}

quickly available in nature. In 2016, the OIE identified more than a hundred infectious animal diseases that can be devised as bioweapons (OIE, 2021).

Bioweapons are effective, toxic, environmentally stable for large geographical area coverage and large scale production for mass casualties and civil disruption. The pathogens need to be stable in aerosol and worthy for being dissipated (5-17 $\mu \mathrm{m}$ particle size) because the aerosol route allows for a massive attack (Kortepeter \& Parker, 1999). They need to be contagious and resistant to treatment or vaccination and enhanced through genetic engineering (Jansen et al., 2014). Environmental conditions and growth phase are significant considerations in the effectiveness of the bioagent (Kaufmann et al., 1997). Smallpox could be a potential bioweapon as there is no vaccine available against it (Whitley, 2003). As pathogen genomic data, the open scientific literature is conveniently accessible on the internet and pharmaceutical manufacturing sites, some anti-social elements may misuse to create malicious bioweapons. The US Centers for Disease Control and Prevention (CDC) has classified potential bioterrorism agents into three priority categories A, B, and C based on their capacity to spread, fatality rates, and disease-causing capabilities. 


\begin{tabular}{|c|c|c|c|}
\hline B & $\begin{array}{l}\text { Brucellosis } \\
\text { Epsilon Food toxicity } \\
\text { Glanders } \\
\text { Melioidosis } \\
\text { Psittacosis } \\
\text { Q fever } \\
\text { Ricin toxicity } \\
\text { Staphylococcal enterotoxicity } \\
\text { Typhus fever } \\
\text { Viral encephalitis } \\
\text { Water safety threats }\end{array}$ & $\begin{array}{l}\text { Brucella sp. } \\
\text { Clostridium perfringens, } \\
\text { Salmonella species, } \\
\text { Escherichia coli, Shigella } \\
\text { Burkholderia mallei } \\
\text { Burkholderia pseudomallei } \\
\text { Chlamydia psittaci } \\
\text { Coxiella burnetii } \\
\text { Ricinus communis (castor } \\
\text { beans) } \\
\text { Staphylococus sp } \\
\text { Rickettsia prowazekii } \\
\text { Alpha viruses } \\
\text { Vibrio cholerae } \\
\text { Cryptosporidium parvum }\end{array}$ & $\begin{array}{l}\text { Moderately } \\
\text { easy to } \\
\text { disseminate, } \\
\text { moderate } \\
\text { morbidity }\end{array}$ \\
\hline $\mathrm{C}$ & $\begin{array}{l}\text { Tuberculosis } \\
\text { Encephalomyelitis } \\
\text { AIDS (acquired } \\
\text { immunodeficiency syndrome) }\end{array}$ & $\begin{array}{l}\text { Mycobacterium tuberculosis } \\
\text { Herpes Simplex Virus (HSV), } \\
\text { SARS, HINI, Nipah virus, } \\
\text { Hantavirus, (Human } \\
\text { HIV Immodeficiency Virus) } \\
\text { Immonod }\end{array}$ & $\begin{array}{l}\text { Easily } \\
\text { produced, the } \\
\text { potential for } \\
\text { high morbidity } \\
\text { and mortality }\end{array}$ \\
\hline
\end{tabular}

Adapted from (Centers for Disease Control and Prevention, 2019)

\section{Targets of Bioterrorism}

Poverty is inextricably linked to bioterrorism which is one of the consequences of climate change, population growth, and poor agricultural practices (Reuveny, 2007). Bioterrorism can be a threat to Agriculture and food consumption in form of agroterrorism by contaminating commodities like vegetables, milk, or meat on the homestead or even in the store with microbial pathogens. Agriculture specialization is increasing along with our understanding of crop diseases making certain areas or countries highly vulnerable to agroterrorism. Wheat smut fungus (Tilletia $s p$.), rice false smut (Ustilaginoidea virens), rice blast disease (Magnaporthe grisea), potato late blight (Phytophthora infestans), wheat rust disease (Puccinia graminis) etc., have been considered as potential agroterrorism agents (Sinha \& Singh, 2016). There are exotic plant pathogens that could devastate the crop for the rest of the year and probably permanently if introduced mistakenly. Insect-vectored bacteria, phytoplasmas, or viruses are highly probable weapons in Agroterrorism (AGRIOS, 2017).

\section{History of Bioterrorism}

Biological warfare has gradually evolved for nearly 2,500 years from propelling plague victims to the intentional use of contaminated materials (Robertson \& Robertson, 1995). It had been addressed for centuries, and many countries were already producing and stockpiling pathogens, like the Bacillus anthracis for potential use against the rival army in battle. The first documented event of bioterrorism appeared in the Mesopotamian 
city in $600 \mathrm{BC}$ where they used dead animals as biological agents to foul the enemies water supply. They used rye infected with ergot fungus Claviceps purpurea which release mycotoxin ergotin (Rega, 2004). In 1346, the military attack of Crimea controlling Genoa seaport in Italy spread the Plague which was the most catastrophic public health disaster to hit Europe and North Africa killing more than 25 million Europeans. The Russian army was accused of using plague infected corpses against the Swedish army in 1710 . Besides this, during the French-Indian War of 1754-1767, the British were accused of deliberately using smallpox to reduce the native Indian population (Christopher et al., 1997). During World War I, ricin (a highly toxic, natural protein) extracted from Castor (Ricinus communis) was used in powder form as a biological weapon for shotgun and shrapnel coating (Smart, 1997). Similarly, the Russian army assassinated Bulgarian exile Georgi Markov who was stabbed with an umbrella that injected with a tiny pellet containing ricin (Smart, 1997). The first bioweapon attack on the United States was in 1984, when followers of the cult Rajneesh poisoned salad bars in Oregon with Salmonella typhimurium, resulting in serious food poisoning in thousands of people (Caudle III, 1997; Christopher et al., 1997). Iraq developed offensive biological weapons capacity in 1990, which included Anthrax, botulinum toxin, and aflatoxin. A further assault in Japan by the fatalist cult Aum Shinrikyo sparked the worldwide crisis as his followers discharged sarin, a neurotoxin into the Tokyo subway system on March 18, 1995 (Asukai \& Maekawa, 2002).

In the preceding paragraph, the Bioterrorism of the twentieth century was discussed. In the following paragraph, the attempt of bioterror in the twenty-first century is discussed. Bioterrorism appeared in the fall of 2001 in the US when people in various positions in politics and on television news received letters that included spores of the bacterium Bacillus anthracis, the pathogen of Anthrax (AGRIOS, 2017; Salem, 2003). There is a global threat of nuclear attack by North Korea as several missile trials are in progress there. Among the numerous bioweapons believed to be in the trial phase by the North Korean military are anthrax, botulism, cholera, plague and smallpox (Kristensen \& Norris, 2018; Reynolds, 2021). Several nations have been experimenting and stockpiling pathogens that can invade and ruin economically important food crops such as rice, potatoes, wheat, beans etc. that could impact food availability (AGRIOS, 2017). The concept of dual-use research emerged in early 2001 when an experiment was conducted by an Australian scientist group to develop a viral contraceptive to control rodent populations. They changed the mousepox virus from a benign to a highly lethal form by inserting an immune system protein gene into it. This discovery could provide a 'roadmap' for terrorists to develop more lethal humaninfecting viruses (Atlas \& Dando, 2006). The advancement of these weapons can be traced back to modern biotechnology research, which has resulted in significant advances in agriculture and industrial processes.

\section{Present Scenario Bioterrorism}

The international community is struggling in combating the COVID-19 pandemic, which caused an estimated monetary loss of 76.69 billion dollars, engulfed more than 5.2 million people. More than 267 million people have suffered to date, and eight billion vaccine doses have been administered across the globe (WHO, 2021). The first reports in late 
2019 revealed that a zoonotic virus SARSCoV-2 was spreading from Wuhan, China. It was thought to have been disseminated from an animal reservoir at a live-animal market (Knight, 2021). COVID-19 instances have increased dramatically worldwide since February 2020 (Himalayan Times, 2021; UN Chronicle, 2020).

Several nations have suspected the virus as a biological weapon. US authority investigated the virus, its outbreaks transmission progression, and disease severity (Gomes, 2020). They pointed to the country of origin i.e China for the spread of the virus due to lack of transparency from Chinese authority. In 2015, the Wuhan Institute of Virology (WIV) was upgraded to the National Biosafety Laboratory (Level 4), the first of its kind in China, at a cost of 300 million Yuan (\$44 million) (Chaturvedi et al., 2020). It would not be the first time that modern research in China drew the attention of the international community. In late 2018, the announcement of human gene editing resulted in criminal charges against Chinese biophysicists (Cohen \& Normille, 2020). US officials and senators suspected that the Corona virus may have leaked accidentally or otherwise virus was intentionally spread from the WIV laboratory in the central Chinese city of Wuhan where the virus was first recorded. Legitimate viral research was performed despite of identification of safety concerns at this laboratory (Rogin, 2020; Stevenson, 2020). It is suspected that from research on Corona viruses in bats have been studied at the Wuhan Institute of Virology (WIV) for over a decade (Hu et al., 2015). The lab worked on Corona viruses (CoVs) and the causal agents of the 2003 SARS outbreak were under study in the lab. In $2015 \mathrm{Hu}$ and his colleagues published reports about the species of bats acting as natural reservoirs for SARS and pointed out the genetic diversity of the viruses in bats, highlighting the possibility of them infecting humans. Bat Corona viruses have received special attention because two emerging Corona viruses Severe Acute Respiratory Syndrome Corona virus (SARS-CoV) and Middle East Respiratory Syndrome Corona virus (MERS-CoV) have caused unexpected human disease outbreaks in the twenty-first century. Various species of horseshoe bats in China have been identified to have SARS-like Corona viruses that are genetically diverse (Hu et al., 2015).

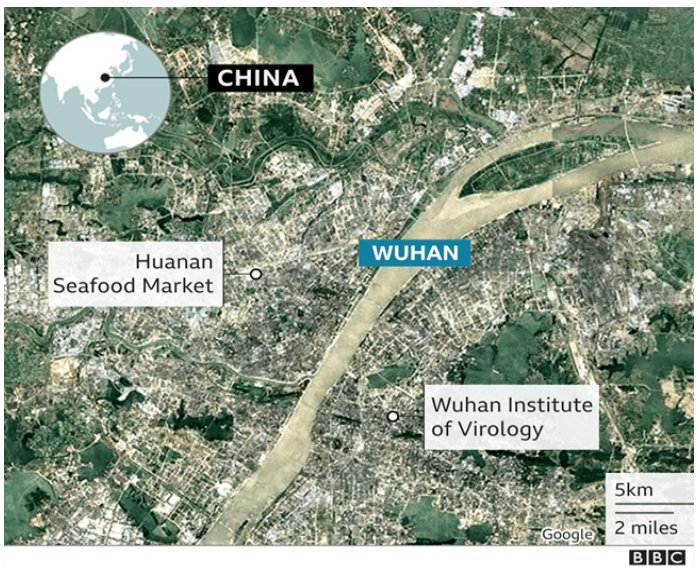

Fig.1: Place of showing the location of Corona virus spread (BBC, 2021)

The novel coronavirus has the potential to weaken many societies, political systems, and economies. Even the most powerful nations are facing several challenges COVID-19, as no other country was prepared to deal with the pandemic. The pandemic had a direct impact on the social, political, cultural, economic status of humans globally (Davies, 2008; Tandon, 2020). COVID-19 has taken a toll on human life, negatively affected the psychological aspects of many lives and has completely changed the way people are conducting their daily routines (Karki, 2021). 


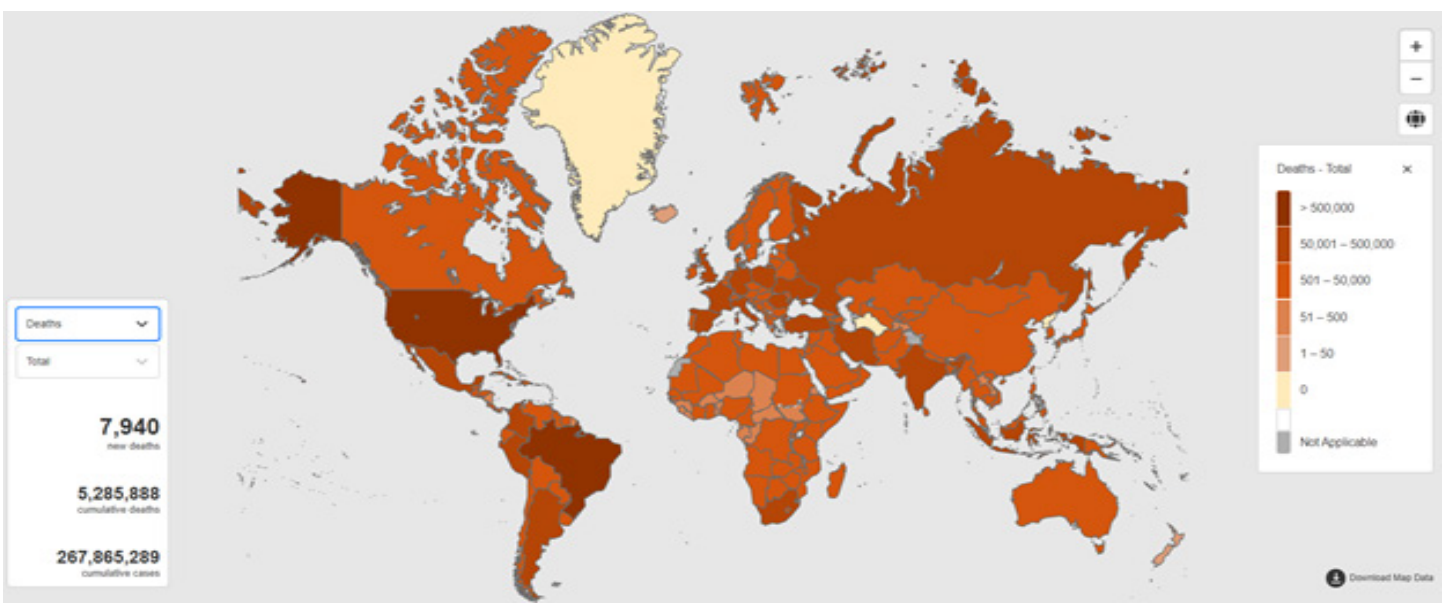

Fig.2: World map showing total deaths due to covid 19 (WHO, 2021)

\section{Awareness and control measures}

Public health is an important pillar of any national security framework. Bioterrorism has the potential to wipe out an entire population in a short time. It can harm animals and damage harvested crops. Therefore an effective response is required against bioterrorism. This can be achieved through multi-modal and multi-agency approaches (Sinha \& Singh, 2016). In this biotechnological era, we have to think critically about all dimensions of security. Advances in biotechnology will aid in the development of better and faster detection of bioweapon. Effective control measures against bioterrorism include vigilance tools, research programs, planning for risk management and the anti-bioterrorism act. Furthermore, preparatory identification of biological agents is made using mobile faster units, which play a key role in the surveillance activities, and numerous these technologies should be used more often in the future (Grundmann, 2014). A multitude of detection techniques has been created which can take a few hours to several days to diagnose vulnerability to a biological weapon. SMART (Sensitive Membrane Antigen Rapid Test), JBPDS (Joint Biological Point Detection System), and BIDS (Biological Integrated Detection System) are examples of current detectors (Acheson, 2021). The treatment of biological warfare victims is heavily reliant on the establishment

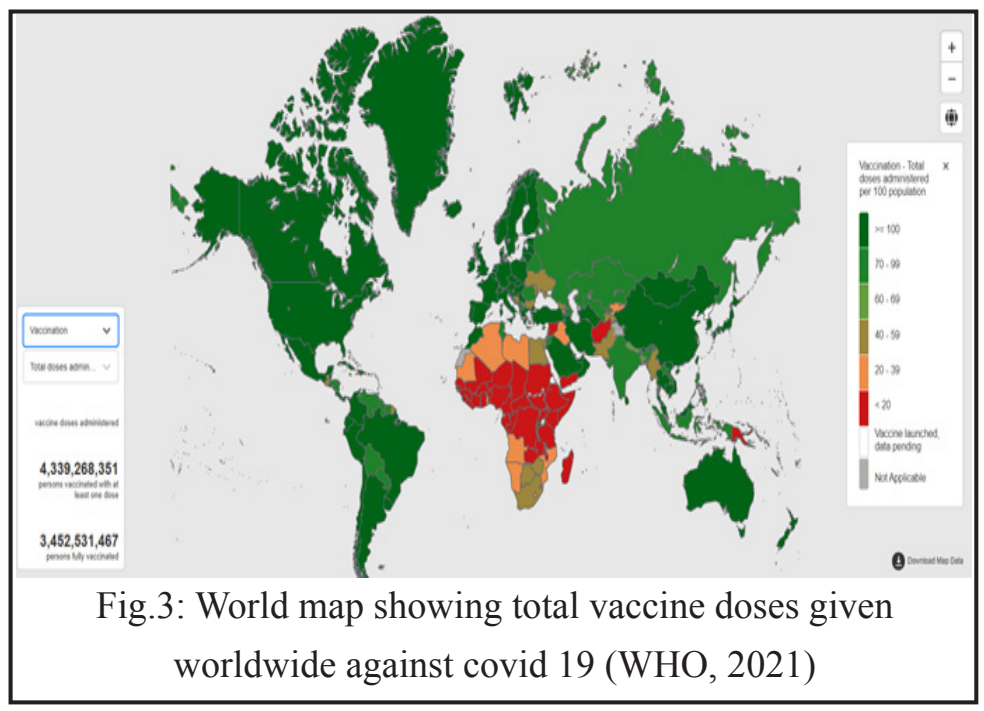


and maintenance of a good healthcare system.

Several policies andagreements are formulated at international levels to discourage the use of Bioagents. In 1972, the Biological Weapons Convention became the first convention to prohibit the creation, manufacturing, stockpiling, and purchase of biological weapons but this treaty does not prevent the non-hostile employment of biological agents (Enemark, 2010). Poisonous and asphyxiating fluids, as well as bioagents, were outlawed in warfare under the Geneva Protocol of 1925. Similarly 'Customary international law' banned possession and use of bioweapons (Protocol, 1925). These laws contribute to the effective operation and proper regulation of security institutions and also to qualify them enough to handle the challenges that threaten national security. Collaborative non-aligned relations with neighbouring nations as well as careful oversight of biosecurity related activities by concerned national authorities will be beneficial for the procurement of a sound biosecurity system (Kharel, 2021). Multi-agency collaborative and coordinated actions are underway to effectively restrict the intentional or unintentional exposure of biological materials. It is high time to take certain initiatives for collaborative approaches among the researcher, university students and national security wing for national biosecurity. Such activities are necessary to fight the uncertainty coming nearby the future.

\section{Biosecurity in Nepal}

First paragraph deals with the Challenge of Biosecurity whereas the second paragraph deals with Prospects of Biosecurity.

\subsection{Challenge of Biosecurity}

There is a gap in the assimilation, cooperation, and collaboration of various security agencies of Nepal in national security. Nepal must modernize its security apparatus for the protection of her sovereignty among these powerful Asian countries, (Karki, 2021). The factors contributing to the deterioration of Nepalese security are Political instability, impunity, transitional injustice, natural disasters, and financial irregularities (Wagle, 2013). The open border with India on three sides is viewed as a major threat posing a significant challenge to the national biosecurity of Nepal (Kharel, 2021). Manual labour drain to India and Gulf countries and brain drain to US and European countries has resulted in the rise of transboundary and transcontinental activities, which brings a variety of biosecurity threats (Kharel, 2021). Migration has been a key factor in the spread of infectious diseases (Wilson, 1995). Humans acquire immunologic sequelae from previous infections and are infected with a variety of pathogens (Wilson, 1995). Major threats are the transport of plantpathogen of staple crops and human lifethreatening diseases like AIDS, COVID-19, Plague, Diarrhea, Cholera etc. The spread of arms and ammunition including the biological contaminated pathogen has the potential of excessive devastation across the nation. Insurgencies, terrorism, outbreaks of infectious diseases, poverty, low educational quality, unemployment, environmental degradation, and other factors have repeatedly threatened National security. There is a lack of quick detection tools for bioagents in developing countries like Nepal. Personal Protective Equipment (PPE), Rapid Detective Test (RDT), Polymerase Chain Reaction (PCR) test, and quarantine facilities will aid in pandemic management to great extent (Giri, 2021). 


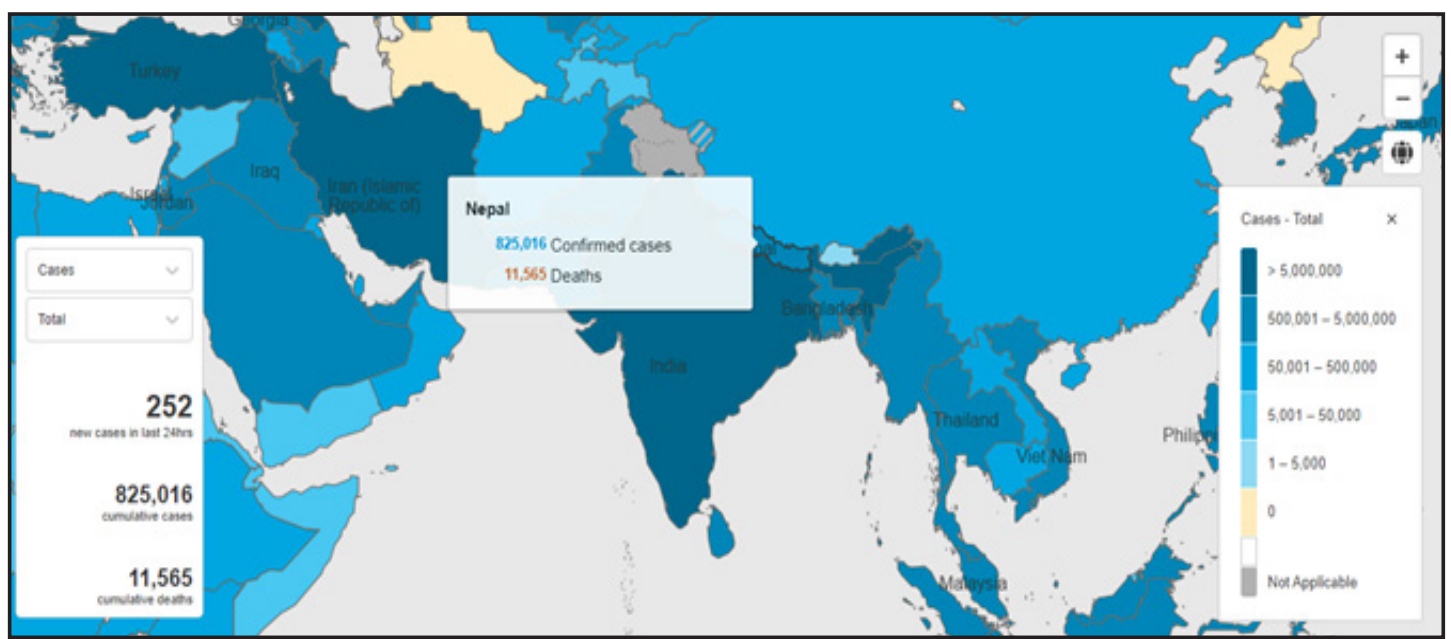

Fig.4: Map of Asia showing total confirmed cases and deaths due to covid 19 in Nepal (WHO, 2021)

Advancement in science and biotechnology is creating new threats to human security. The country's sovereignty, peace, and stability may be jeopardized by the disastrous impact of bioweapons. The situation will continue to deteriorate unless efficient biosecurity measures are taken in Nepal. Nepal biosecurity policies must be updated to reflect shifting biosecurity dangers focusing on health emergency surveillance, perception and readiness tactics.

\subsection{Prospects of Biosecurity}

Bioweapon use will be eco-friendlier and will decrease climate hazards caused due to the use of bombs made up of gun power. In developing countries, nuclear weapons are expensive and have a higher maintenance cost. We can counter-attack with bioweapons made by utilizing our rich flora and fauna. It's time to seek alternate weapons from our rich biodiversity. We can utilize such resources for the welfare of the people and country. Necessary precautions should be followed while researching as there is a high chance of a hazardous outbreak. Biosensor innovation can be developed at the national, regional, and federal levels in association with NAST (Nepal Academy of Science and Technology). State agencies must provide grants in support of biosafety research programs. Legislation must be modified to approve certain pretested bioagents. Furthermore, autonomous agencies of business leaders, government officials, and academic institutions must be formed to structure and systemic change regulations regarding risk assessment.

\section{Conclusion}

Bioterrorism has the potential to wipe out an entire population of a place. Early diagnosis, treatment, and connectivity are critical for an effective response because bioterrorism assaults are unexpected. The study found that the scenario of rising threats of bioterror has become a prominent challenge for Nepal since it has hindered peace, security, and stability. The present COVID-19 pandemic crisis has taught people globally to be prepared for combating bioterrorism. In this study, we came to know that the richness of the biodiversity of Nepal can be utilised for 
combating a foreign terror attack. Several Himalayan medicinal herbs can be utilized for biosecurity. Some potential flora and fauna can be used as a bioweapon to protect the sovereignty of the nation by the national security wings. This will also open the door for research and exploration of national biodiversity potential for new organic compounds we have broad application in public health and agriculture. Research lab biosecurity and legislation must be reviewed and implemented by policymakers. The study found that risk assessments should be done to restrict exposure to agents having the potential of bioterrorism. Our key finding was that the National Security Council, the Nepali Army, the Nepal Police, the Armed Police Force (APF) and the National Investigation Department must work together to combat bioterrorism. Diplomacy and consistent foreign policies with neighbour nations would contribute more towards national security by safeguarding our sovereignty. We concluded that collaboration among alumni, government and private business sector is mandatory to give benefits that go far beyond protection from premeditated acts of bioterrorism.

\section{References}

Acheson, R. (2021). Biological weapons. Reaching Critical Will (RCW). https://www. reachingcriticalwill.org/resources/fact-sheets/ critical-issues/4579-biological-weapons

Ackerman, G. A., \& Moran, K. S. (2004). Bioterrorism and threat assessment (Vol. 22). Weapons of Mass Destruction Commission.

Asukai, N., \& Maekawa, K. (2002). Psychological and physical health effects of the 1995 sarin attack in the Tokyo subway system. In Toxic Turmoil (pp. 149-162). Springer.
Atlas, R. M., \& Dando, M. (2006). The dual-use dilemma for the life sciences: Perspectives, conundrums, and global solutions. Biosecurity and Bioterrorism: Biodefense Strategy, Practice, and Science, 4(3), 276-286.

Balali-Mood, M., Moshiri, M., \& Etemad, L. (2014). Bio Warfare and Terrorism: Toxins and Other Mid-Spectrum Agents. In P. Wexler (Ed.), Encyclopedia of Toxicology (Third Edition) (pp. 503-508). Academic Press. https://doi.org/10.1016/B978-0-12-3864543.00589-3

BBC. (2021). Covid origin: Why the Wuhan lab-leak theory is being taken seriously. $B B C$ News. https://www.bbc.com/news/world-asiachina-57268111

Caudle III, L. C. (1997). The biological warfare threat. Medical Aspects of Chemical and Biological Warfare. Washington, DC: Office of the Surgeon General, Borden Institute, Walter Reed Army Medical Center, 451-466.

Centres for Disease Control and Prevention. (2019, May 15). CDC $\mid$ Bioterrorism Agents/Diseases (by category) | Emergency Preparedness \& Response. https://emergency.cdc.gov/agent/ agentlist-category.asp

Chaturvedi, P., Ramalingam, N., \& Singh, A. (2020). Is COVID-19 man-made? Cancer Research, Statistics, and Treatment, 3(2), 284.

Chaturvedy, R. R., \& Malone, D. M. (2012). A yam between two boulders: Nepal's foreign policy caught between India and China. Nepal in Transition: From People's War to Fragile Peace, Cambridge University Press, New York, 287-312.

Christopher, G. W., Cieslak, T. J., Pavlin, J. A., \& Eitzen, E. M. (1997a). Biological warfare. A historical perspective. JAMA, 278(5), 412417.

Christopher, G. W., Cieslak, T. J., Pavlin, J. A., \& Eitzen, E. M. (1997b). Biological warfare. A historical perspective. JAMA, 278(5), 412417. 
Cohen, J., \& Normille, D. (2020). China delivers a verdict on gene editing of babies. American Association for the Advancement of Science.

Croddy, E., Perez-Armendariz, C., \& Hart, J. (2002). Chemical and Biological Warfare: A Comprehensive Survey for the Concerned Citizen. Springer Science \& Business Media.

Davies, S. E. (2008). Securitizing infectious disease. International Affairs, 84(2), 295-313.

Debnath, M., Prasad, G. B., \& Bisen, P. S. (2010). Molecular diagnostics: Promises and possibilities. Springer Science \& Business Media.

Douglass, J. D., \& Livingstone, N. C. (1987). America the vulnerable: The threat of chemical and biological warfare.

Enemark, C. (2010). The role of the Biological Weapons Convention in disease surveillance and response. Health Policy and Planning, 25(6), 486-494.

Etymonline. (2020). https://www.etymonline. com/

Giri, S. (2021). The Impact of Covid-19 on National Security of Nepal | Unity Journal. https://www.nepjol.info/index.php/unityj/ article/view/38852

G.N Agrios. (2017). Plant Pathology, 5th edn. http://agrihelper.blogspot.com/2016/10/plantpathology-by-gn-agrios-5th.html

Gomes, C. (2020). Report of the WHO-China Joint Mission on Coronavirus Disease 2019 (COVID-19). Brazilian Journal of Implantology and Health Sciences, 2(3).

Grundmann, O. (2014). The current state of bioterrorist attack surveillance and preparedness in the US. Risk Management and Healthcare Policy, 7, 177.

Haq, M. (1995). New imperatives of human security. World Affairs: The Journal of International Issues, 4(1), 68-73.

Himalayan Times. (2021). UN warns cybercrime on the rise during a pandemic. The Himalayan Times. https://thehimalayantimes.com/ world/un-warns-cybercrime-on-rise-duringpandemic

Hu, B., Ge, X., Wang, L.-F., \& Shi, Z. (2015). Bat origin of human coronaviruses. Virology Journal, 12(1), 221. https://doi.org/10.1186/ s12985-015-0422-1

Jansen, H.-J., Breeveld, F. J., Stijnis, C., \& Grobusch, M. P. (2014). Biological warfare, bioterrorism, and biocrime. Clinical Microbiology and Infection, 20(6), 488-496.

Karki, S. (2021). Internal and External Security Challenges of Nepal. Unity Journal, 2, 251-262. https://doi.org/10.3126/unityj. v2i0.38850

Kaufmann, A. F., Meltzer, M. I., \& Schmid, G. P. (1997). The economic impact of a bioterrorist attack: Are prevention and postattack intervention programs justifiable? Emerging Infectious Diseases, 3(2), 83.

Kharel, A. B. (2021). Evolving Dimensions of Security and Its Relevance in Nepal. Interdisciplinary Journal of Management and Social Sciences, 2(1), 5-17.

Knight, D. (2021). COVID-19 pandemic origins: Bioweapons and the history of laboratory leaks. Southern Medical Journal, 114(8), 465.

Kortepeter, M. G., \& Parker, G. W. (1999). Potential biological weapons threats. Emerging Infectious Diseases, 5(4), 523.

Kristensen, H. M., \& Norris, R. S. (2018). North Korean nuclear capabilities, 2018. Bulletin of the Atomic Scientists, 74(1), 41-51.

Maier, C. S. (1990). American Visions and British Interests: Hogan's Marshall Plan. JSTOR.

OIE. (2021). OIE-World Organisation for Animal Health, OIE - World Organisation for Animal Health. https://www.oie.int/en/home/

Protocol, G. (1925). Protocol for the prohibition of the use in war of asphyxiating, poisonous or other gases, and of bacteriological methods of 
warfare. Signed at Geneva, June, 17.

Rasco, B. A., \& Bledsoe, G. E. (2004). Bioterrorism and food safety. CRC Press.

Rega, P. (2004). History of Bioterrorism: A Chronological History of bioterrorism and biowarfare throughout the Ages. Biological Terrorism Response Manual,(on Line a: Http://Www. Bioterry. Com).

Reuveny, R. (2007). Climate change-induced migration and violent conflict. Political Geography, 26(6), 656-673.

Reynolds, J. (2021). The Hermit Kingdom's Forgotten Threat: Evaluating UNSCR 1540's Effectiveness in Controlling North Korea's Biological Weapons Program. Journal of Biosecurity, Biosafety, and Biodefense Law, 12(1), 155-174. https://doi.org/10.1515/ jbbbl-2021-2008

Robertson, A. G., \& Robertson, L. J. (1995). From asps to allegations: Biological warfare in history. Military Medicine, 160(8), 369-373.

Rogin, J. (2020). State Department cables warned of safety issues at Wuhan lab studying bat coronaviruses. Washington Post. https://www. washingtonpost.com/opinions/2020/04/14/ state-department-cables-warned-safetyissues-wuhan-lab-studying-bat-coronaviruses/

Salem, H. (2003). Issues in chemical and biological terrorism. International Journal of Toxicology, 22(6), 465-471.

Sinha, S., \& Singh, J. (2016). Classification, Causes, Control Measures and Acts of Bioterrorism. International Journal of Applied Biology and Pharmaceutical Technology, 7,
$342-354$.

Smart, J. K. (1997). History of chemical and biological warfare: An American perspective. Medical Aspects of Chemical and Biological Warfare. Washington, DC: Office of the Surgeon General, 9-86.

Stevenson, A. (2020). Senator Tom Cotton Repeats Fringe Theory of Coronavirus Origins. The New York Times. https://www. nytimes.com/2020/02/17/business/media/ coronavirus-tom-cotton-china.html

Tandon, P. N. (2020). COVID-19: Impact on health of people \& wealth of nations. The Indian Journal of Medical Research, 151(23), 121.

UN Chronicle. (2020). 2020, COVID-19 and the Climate Agenda. United Nations; United Nations. https://www.un.org/en/unchronicle/2020-covid-19-and-climate-agenda

Wagle, G. S. (2013). Political insecurity and armed conflict: A threat to human security. Human Security in Nepal: Concepts, Issues and Challenges, 1, 251-278.

Whitley, R. J. (2003). Smallpox: A potential agent of bioterrorism. Antiviral Research, 57(1-2), 7-12.

WHO. (2021). WHO Coronavirus (COVID-19) Dashboard. https://covid19.who.int

Wilson, M. E. (1995). Travel and the emergence of infectious diseases. Emerging Infectious Diseases, 1(2), 39-46. 